\title{
Unconventional Gas in the Benelux: Cautious Attitudes and Regional Interplay
}

\author{
Simon G. J. Devos \\ Technical University of Applied Sciences, Wildau, Germany
}

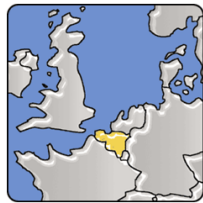

Abstract. The three countries of the Benelux are often overlooked in Europe's current unconventional gas debate. But the Netherlands, Belgium and Luxembourg all possess considerable shale gas resources, and major energy companies have already taken an interest. So far no serious drilling has taken place. This article puts the discoveries and recent action in the perspective of regional breakdown of public policy and government authority. Analyzing business prospects, economic policy and regulatory action of the different governments in the Benelux, the article yields insight into the relevant power structure inside the policy domain. The influence of different members of the Benelux on the other members is discussed. All three countries have adopted a rather cautious attitude towards the exploration and production of unconventional gas.

Keywords: Belgium, Benelux, chemical industry, coalbed methane, energy, energy policy, Flanders, fracking, hydraulic fracturing, Luxembourg, regulatory politics, Royal Dutch Shell, shale gas, The Netherlands, unconventional gas

Author: The author is an M.A. candidate in the European Management program at Technical University of Applied Sciences, Wildau, Germany, and the M.A. program in Management of European Affairs at Université des Sciences et Technologies de Lille (Lille I), France. He holds a B.A. in business management from Katholieke Hogeschool Zuid-West-Vlaanderen (now Vives) in Kortrijk, Belgium.

\section{Introduction}

The "Benelux" is, contrary to popular European usage of the term, not just a handy acronym for a geographic and cultural group of three countries within the EU. It is a true formal union of states, complete with executive, legislative and judiciary institutions and a long history of intergovernmental cooperation. The union goes back to a 1944 customs agreement and the 1958 treaty which established the Benelux Economic Union. In 2008, the treaty was renewed and the name shortened to Benelux Union. As the original name implies, economic cooperation is at the heart of the Benelux. Thus, the development of unconventional gas resources should be a matter of this union.

However, analyzing policy on unconventional gas on a Benelux level is not an easy thing to do. The Benelux Economic Union has an administration (the Secretariat-General in Brussels) and a parliamentary assembly. The parliament not possess any specific powers within the energy policy area and specifically, the unconventional gas issue. It does not engage in lawmaking but has a role in information exchange among parliaments of the member states, and advises member states on international economic cooperation.

Strictly taking to the constitutional organization of the Benelux member states, at least ten involved governments can be identified, eight of which are part of the complex political landscape of Belgium:

- the Cabinet of the Netherlands, representing the Dutch citizens in all matters,

- the Council of the Government of Luxembourg, representing the citizens of Luxembourg in all matters,

- the Federal Government Council of Belgium, representing the citizens of Belgium in certain environmental and energyrelated matters,

- the Flemish Community of Belgium, representing the Dutch speaking citizens of Belgium in social matters,

- the Flemish Region of Belgium, representing Flemish citizens in economic and environmental matters,

- the Walloon Region of Belgium, representing the Walloon citizens in economic and environmental matters,

- the Wallonia-Brussels Federation of Belgium, representing the French speaking citizens of Belgium in social matters,

- the German-speaking Community of Belgium, representing the German speaking citizens of Belgium in social matters,

- the Brussels-Capital Region of Belgium, representing the Brussels citizen in economic and environmental matters.

In addition, the provinces of both Belgium and the Netherlands have specific executive powers within the environmental policy domain, but they are considered to not be of high importance for legislative decisions. The state organization of the Kingdom of Belgium is changing. From July 2014, the Communities and Regions will obtain extra powers in environmental and energy policy. 
Via analyzing recent news coverage from both local and international press, policy makers' speech and scientific articles, this article focuses on the main responsible governments within the policy domain of unconventional gas. The first main section draws a basic sketch of those stakeholders, highlighting their history, future prospects, public policy actions, and businessgovernment relations in relation to unconventional gas. A shorter second section specifically focuses on recent intergovernmental developments and actions between Flanders and the Netherlands, the two Dutch-speaking members of the Benelux area.

\section{The Netherlands}

The Netherlands have a long history in drilling for conventional gas. Today, they are the largest EU gas producer and exporter: "Although they have passed the point of peak gas production and our gas reserves are diminishing, the Netherlands can maintain its current position until around 2025" (Government of the Netherlands, 2013). But as its conventional gas reserves from the large Groningen gas fields are shrinking, the Netherlands are looking for a replacement. Gas revenues yield $€ 15$ billion a year currently; 42 percent of the nation's energy comes from natural gas, which is an exceptionally high share in Europe (Steinglass, 2013). Gas as an energy source is not uncontroversial. Since 1986, multiple earthquakes have occurred in the Netherlands because of the extraction of gas, resulting in much critical debate and public opinion being rather pessimistic about further extraction of gas in the Netherlands (Heylen, 2013).

Currently, conventional gas extraction is mainly operated by the Nederlandse Aardolie Maatschappij, co-owned by Royal Dutch Shell and ExxonMobil. This company does have the technology and know-how available to extract shale gas in the Netherlands. One NAM executive has clearly stated: "We have built up years of experience in extracting gas within the Netherlands, and we used fracking to extract some of our conventional gas fields, so we can and should definitely explore this now" (Windhorst, 2012).

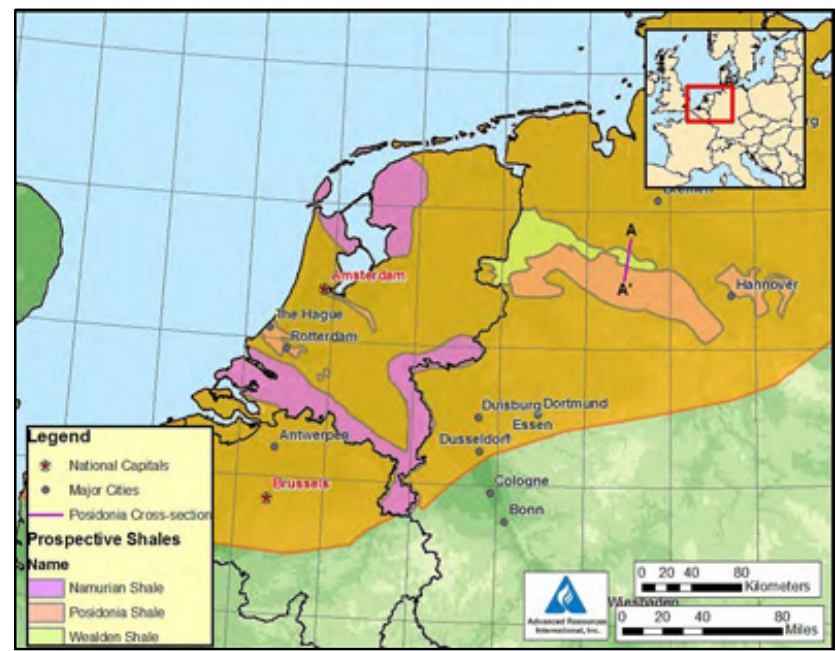

Figure 1: Principal shale gas basins in Western Europe (U.S. Energy Information Administration, 2011).

Gasunie, the Dutch state-owned gas distribution company, has been developing an important network for the transportation of gas in Europe. The company built its reputation on the transportation of Dutch conventional gas, and is definitely looking for new ways to keep its reliability high in the future. In Bergermeer, Gasunie is currently realizing a gas storage facility via its subsid- iary Gas Transport Systems. After some lobbying, Gazprom also became a shareholder in this project, with a capacity of two billion cubic metres per year (Medvedev, 2013), which is approximately 42 percent of the total capacity of the storage facility. But the Dutch government is not really keen on further cooperation with Gazprom after severe incidents on the extraction of gas between the company and Royal Dutch Shell during the Sakhalin II-project in the Russian Arctic. A Gasunie manager stated, "shale gas is a very interesting opportunity for Gasunie and the Netherlands to keep its independence and reliability on the transportation of gas in the future" (Verberg, 2013).

The reserves of shale gas in the Netherlands are estimated between circa 200 and 500 billion cubic metres (Zijp, 2012). The map of figure 1 shows the area where unconventional gas can be found in the Netherlands.

Quite a lot of the possible extraction territories within the Netherlands have been given as concessions to a company. At present, the Dutch public authorities have provided a company, Brabant Resources BV, a license to start test drilling for shale gas in Boxtel in the Flevoland province, one of the most promising areas to extract shale gas in the future. The company, which is minority state-owned (40 percent of the shares of Brabant Resources BV are owned by the state-controlled EBN BV, which also invests in other unconventional gas projects in Northern Europe). This company is the only one so far who has really wanted to start exploring shale gas; but its license has been suspended in March 2012 because of strong opposition from both citizens and local public authorities. "Public support is very important to realize this project, and at present, there is no public support", argued activist Stijn De Klerk (2012), member of the action committee "Shale-free Boxtel."

Boxtel is not the only place where communities have voiced strong opposition and local authorities have announced they would deny well permits. The Netherlands are known for a very active scene of environmental groups, and their arguments that the Dutch have location-specific problems because of high population density, complex infrastructure and too permeated with water convinced many locals to be cautious about "fracking." A spring 2013 public opinion survey by polling firm Maurice de Hond showed 44 percent against and 35 percent in favor of developing shale gas (Steinglass, 2013). "Opponents are winning the Dutch shale gas war," declared a newspaper in April 2013:

Support for extracting shale gas from under the Netherlands is fading and an increasing number of local councils are taking a stand [...]. So far, 33 of the country's 400 local authority areas have declared they are opposed to shale gas extraction [...]. Some 170 councils are thought to be sitting on shale or coal gas reserves. The Netherlands' shale gas reserves could run into billions of euros but it is unclear if the gas will ever be extracted because of the wellorganised opposition [...]. [However, the] national government can still overturn local council objections and press ahead with shale gas extraction. (DutchNews.nl, 2013).

As a result of this fierce conflict, industry now faces a moratorium on all licenses for shale gas in all of the Netherlands. It should be noted that the Dutch political culture is very orientated toward consensus building, and public support across a range of stakeholders in society has high priority for government action. Foreign companies and investors in the Dutch economy, too, have to adjust to this slow-moving, step-by-step process. Rush decisions are rare.

Five main players are operating in the Netherlands: NAM, NPN, Brabant, Vermilion, and Hardenburg. As Table 1 shows, British firms have a major influence in the Dutch unconventional gas business. Geographic proximity and experience on the home market makes the UK without any doubt the most important acting country on the Dutch unconventional gas market. The Dutch people themselves only have minor claims on the Dutch 
unconventional gas resources: the Dutch state directly controls 40 percent of Brabant Resources BV, and indirectly the Dutch dynasty, since "the Dutch Royal Family is still reputed to be the single largest shareholder of Royal Dutch Shell, [...], via owning between 5 and 25 percent of the shares" (Queen Wilhelmina State Park, 2012). This situation could make it harder for public opinion to accept extraction of unconventional gas, as the citizens do not see a direct advantage by gaining extra revenues for the Dutch government (aside from taxing the foreign firms). As the Netherlands is still self-sufficient in conventional gas, the country does not directly have to fear high market prices for imports. In case of emergency, the government could even decide to regulate gas prices down for the current market players.

\begin{tabular}{|l|l|c|c|}
\hline \multicolumn{1}{|c|}{ Full name } & Owned by & Share & $\begin{array}{c}\text { Country } \\
\text { of Origin }\end{array}$ \\
\hline $\begin{array}{l}\text { Nederlandse } \\
\text { Aardolie Maat- } \\
\text { schappij BV } \\
\text { (NAM) }\end{array}$ & $\begin{array}{l}\text { Royal Dutch } \\
\text { Shell Plc }\end{array}$ & $50 \%$ & $\begin{array}{c}\text { NL } \\
\text { UK }\end{array}$ \\
\cline { 2 - 4 } & $\begin{array}{l}\text { Exxon Mobil } \\
\text { Corp. }\end{array}$ & $50 \%$ & USA \\
\hline $\begin{array}{l}\text { Northern Petro- } \\
\text { leum Nederland } \\
\text { BV (NPN) }\end{array}$ & $\begin{array}{l}\text { Northern } \\
\text { Petroleum Plc }\end{array}$ & $100 \%$ & UK \\
\hline $\begin{array}{l}\text { Brabant } \\
\text { Resources BV } \\
\text { (BR) }\end{array}$ & $\begin{array}{l}\text { Dutch } \\
\text { Government }\end{array}$ & $40 \%$ & NL \\
\cline { 2 - 4 } & $\begin{array}{l}\text { Cuadrilla } \\
\text { Resources Ltd }\end{array}$ & $60 \%$ & UK \\
\hline $\begin{array}{l}\text { Vermilion Oil \& } \\
\text { Gas Netherlands } \\
\text { BV (VERM) }\end{array}$ & $\begin{array}{l}\text { Vermilion } \\
\text { Energy Inc. }\end{array}$ & $100 \%$ & Canada \\
\hline $\begin{array}{l}\text { Hardenburg } \\
\text { Resources BV } \\
\text { (CUA) }\end{array}$ & $\begin{array}{l}\text { Cuadrilla } \\
\text { Resources Ltd }\end{array}$ & $100 \%$ & UK \\
\hline
\end{tabular}

Table 1: List of companies with licenses for the exploration and production of unconventional gas in the Netherlands, 2012.

Based on 'Licenses in the Netherlands, April 2012' (Netherlands Organisation for Applied Scientific Research TNO, 2012), and information retrieved from the Dutch Chamber of Commerce.

Speaking about the royal family of the Netherlands, King Willem-Alexander der Nederlanden, who stepped to the throne in April 2013, may have a special role in the country's direction. As former president of the United Nations Secretary-General's Advisory Board on Water and Sanitation (UNSGAB), it is clear that the king has a particular interest in water-related issues. Due to the fact that King Willem-Alexander is a de facto member of the Dutch government, his opinion on water-related topics, like the extraction of unconventional gas, will be taken into account when taking political decisions in the Netherlands. As his mother Beatrix before him, he will be talking to cabinet members and the prime minister on a regular basis (Te Velde, 2013). On the unconventional gas issue, the king may face a serious conflict of interest: on the one hand, his work in favor of clean water supply suggests a stand critical of "fracking" methods, but he has a vested interest in one major unconventional gas developer, Royal Dutch Shell. It will be seen how the king positions himself.

Oil and gas companies are of course not the only stakeholders in the debate. Some major players of the Dutch economy, from breweries to banks, have chosen to take a stand. Like in Germany, the country's brewers are a formidable lobby and an important industry with considerable influence on media and public opinion. Major companies like Heineken, Grolsch, and Bavaria are member of the brewers' union, which has taken a critical position, fearing for the quality of their products' main ingredient - water. In April 2013, the Union of Dutch Brewers announced:
[The] extraction of shale gas and other activities within the soil should not have an effect on the ground water. As long as that is not proven, we are very concerned about the extraction of shale gas (Marijnissen, 2013).

The biggest banking and financial services company of the Netherlands, Rabobank (Coöperatieve Centrale Raiffeisen-Boerenleenbank B.A.), has also expressed its concerns on the exploration and production of unconventional gas in the Netherlands. It even moved to use its power position to influence the debate on shale gas. In July 2013, a Rabobank spokesman said on TV:

The bank does not lend money to companies that have something to do with the extraction of shale gas. Farmers who rent their land to extract shale gas from the soil do not get any further loans from us (NOS, 2013)

These public statements came while the Dutch government was waiting for the outcome of a major study by the Technical University of Delft, which was intended to become a basis for decisions on the future of the moratorium. This study should have been published by end of 2012, but was only been passed to the Dutch government by mid-2013. The Dutch Commission of Environmental Impact Assessment received this study, but declared that "answers on serious issues related to drinking water supply and the interests of local residents are missing" (Postma, 2013). The current cabinet of Prime Minister Mark Rutte, a coalition of the conservative-liberal People's Party for Freedom and Democracy (VVD) and the social democratic Labor Party (PvDA), has internal conflicts about energy policy. Generally, "the conservative-liberal fraction is not happy with the antiunconventional gas position of its government partner" (Simons, 2013). The social democratic party stated that "the extraction of shale gas will not have a fundamental positive impact on the energy economy in the Netherlands, because shale gas reserves are much lower than conventional gas reserves" (Simons, 2013).

By the end of the summer, a government-commissioned report by a consulting consortium suggested that shale gas drilling could be done safely and with minimal ecological impact. One key argument was that Dutch shale gas reserves lie deep, much deeper than in the U.S. for example. Economic affairs minister Henk Kamp (VVD) responded to the report, "if shale gas can be exploited in a responsible fashion in the Netherlands, and if we have it in economically interesting quantities, then we should seriously consider doing so" (Steinglass, 2013).

But the results of the various studies did not convince the Labor Party, which had voted against "fracking" in a spring 2013 party congress. So the Dutch coalition government could only agree to delay its decision. Licensed companies cannot proceed, and new applications will not be administered. The government announced that it would take 18 months for further study on the potential effects of hydraulic fracturing on the environment in all potential drilling sites. Minister Kamp also said he wanted more input from local governments, and would examine how local governments could "wield more influence in establishing conditions under which licenses for the exploration and possible drilling would be issued" (UPI, 2013).

\section{Belgium}

\section{Federal government}

The Belgian situation for developing policy on unconventional gas situation is very special. Responsibility is dispersed among different communities, regions and the federal government. Different political parties govern on different levels. The Belgian federal states have diverging economic situations, and different 
opportunities for the exploration of shale gas exist. Moreover, as mentioned above, the Belgian government system is undergoing reform, shifting policymaking powers to lower levels, i.e. communities and regions.

At present, the most important policy domain on the federal level of Belgium which can influence the unconventional gas debate, is energy policy. There are some environment-related powers that are currently held by the federal government, but the center of gravity lays with the states. At the moment, the State Secretary for Environment, Energy and Mobility, Melchior Whatelet (Humanist Democratic Centre, French-speaking), is administering both policy domains on the federal level. In February 2013, the liberal group within the federal parliament asked Whatelet to his opinion on shale gas, and he answered:

I don't say yes, but I don't say no either to the extraction of shale gas. [...] I am closely following international studies on the topic. If we find out that there are possibilities for shale gas extraction, we would need to examine the question, taking into account both economic potential and potential environmental consequences (De Becker, 2013).

As the two main regions of Belgium, Flanders and Wallonia, have a completely separated public opinion context - basically because of a different language and separated media landscape and different opportunities to produce unconventional gas, this article speaks in more detail about the different communities and regions involved in the unconventional gas debate in Belgium. From a constitutional point of view, the states have their own right to decide in favor or against unconventional gas.

\section{Flemish Community and Flemish Region}

Strictly spoken, Flanders consists of both a Flemish Community (responsible for social matters), and a Flemish Region (responsible for environmental and economic matters). But the Flemish Community and Region merged several years ago. There is thus only one parliament elected for Flanders. In Flanders, two different types of unconventional gas are available. There are possibilities to extract both coalbed methane and shale gas. Coalbed methane can be found in the old abandoned mines in Limburg, and hydraulic fracturing is not needed to extract the gas. According to a survey conducted by VITO [Flemish Institute for Technological Research], at least 7.7 billion cubic metres recoverable methane gas can be extracted in the Campine Basin: "That seems a lot, but it is less than half of the annual natural gas consumption in Belgium" (Grietens, 2013).

NV Mijnen, a wholly-owned subsidiary of Limburgse Reconversie Maatschappij, has obtained approximately 80 percent of all coalfield concessions in Flanders (Dart Energy Limited, 2011). This company set up a joint venture with Australia's Dart Energy, called NV Limburg Gas, with 20 percent of the shares in the hands of Dart Energy. The company has applied for a license to start research for coalbed methane in the Limburg area in April 2013 from the Flemish Ministry of Environment. In the next two years, NV Limburg Gas has the opportunity to conduct detailed studies. After this phase, the company will have to ask for extra permits before real drilling can start: an environmental impact report needs to be delivered, an environmental permit and a building permit must be applied for (Vandenhove, 2013).

Otherwise, there seem to be no ongoing studies in the Limburg area. According to one report, Catholic University of Leuven has asked Royal Dutch Shell for $€ 100,000$ support to investigate unconventional gas layers in Limburg, but Shell found it too expensive (Thuwis, 2013). Another study was offered but not implemented by CWC Group, which represents Shell, Total and ExxonMobil (Van Horenbeek, 2013). As regarding permits, by April 2013 five companies had asked for administrative infor- mation on necessary permits to extract unconventional gas in Flanders, but none laid a concrete application on the table (Vanaudenhove, 2013). Although possibilities to extract coalbed methane in the Limburg area exist, the unconventional gas run in Flanders is not as advanced as in the Netherlands.

One aspect which drives the debate are energy prices. Currently, Belgian energy consumer pay very high prices compared to neighboring countries, the Belgian Commission for the Regulation of Electricity and Gas (2012) has concluded. The Flemish government is concerned about the competitive position of the Flanders economy, and specifically the position of the chemical sector near the Port of Antwerp, which would profit from lower energy costs.

Other economic aspects pertain to recent job losses and business instability. The region where most gas would be extracted, Limburg, is currently suffering from the economic and financial crisis. For example, car manufacturer Ford recently decided to close its factory in Genk in 2014, a hard blow for the region. If the economic situation does not improve in the mid-term, the Flemish government would have a strong incentive to pursue new opportunities. But at the moment, the government seems not keen on making it easy for companies willing to drill. It has decided to postpone a decision until a report on the chances of unconventional gas in Flanders and the environmental effects of "fracking" has been delivered by NV Limburg Gas. Flemish Prime Minister Kris Peeters has stated that the government is not about to rush:

We will take our time to form our opinion on shale gas. It is clear that the industry in the United States of America has grown very fast because of cheaper energy. But in Europe, the sensitivity of the population to environmental cases is a lot higher (De Roo, 2013).

Several interest groups, such as Vlaams Netwerk van Ondernemingen, the Flemish Chamber of Commerce, and Bond Beter Leefmilieu, the main Flemish group for a better environment, have presented their position on the issue, but so far an extensive public debate has not taken place in Flanders.

\section{Walloon Region}

At present, there are no reliable studies that confirm that Wallonia has shale gas available in its soil. There is some evidence that the Walloon mining areas also contain coalbed methane, but there is little data and understanding of the geology, much less certainty about the volume of technically recoverable gas (Cornet, 2013). According to researchers at Mons University, the total amount of coalbed methane available for extraction is between 100 and 300 billion cubic metres, which is significantly more than the quantity in Flanders. "[The Walloon reserves] can provide Belgium with gas for approximately 10 years. That is a significant quantity, but it is not a gold mine for Wallonia," it is reported (Radio et Television de la Belgique francophone, 2013).

The most interested partners to extract gas in Wallonia are Royal Dutch Shell and Albert Frère. Several newspapers state that Shell is rumored to have started a research project in Wallonia. The projects of Albert Frère, the richest citizen of Belgium, do have visible traces. In 2008, his first ideas were launched to extract coalbed methane, and some consultancy activities took place via Transcore Astra SA, a subsidiary of one of his holdings called CPN. Transcore Astra, nowadays known as one of the specialists in the extraction of coalbed methane, has obtained two licenses on the mine gas in Charleroi from Gaznor SA, and is now exploring the potential (Le Soir, 2013). Moreover, the company is applying for a license to restart operating old gas tanks of Fluxys, the Belgian gas distributor, in Anderlues. This gives some focus for the unconventional gas debate in the region (Le Soir, 2013). As Frère is one of the most influential 
businessmen of Belgium (he made his fortune taking over stateowned companies), it is expected that he has realistic chances. Just like in Flanders, a broad public debate on unconventional gas has not yet taken place, which could also help Albert Frère to get his licenses and permits quickly.

\section{Other regions}

Neither the Walloon nor the Brussels-Capital Region nor the German-speaking community have shale gas reserves. The only unconventional gas available is coalbed methane in the Liege area. As a vast majority of votes within the Wallonia-Brussels Federation are held by politicians from Wallonia, and because of Brussels' low interest, the influence of Brussels in public debates would be low. Future decisions taken by the Walloon Region are likely to be supported by the Wallonia-Brussels Federation.

\section{Luxembourg}

In Luxembourg, a debate on unconventional gas has already taking place. In November 2012, the government decided to forbid extraction of unconventional gas using "fracking" methods, due to possible environmental impacts. The reason was that shale gas found in Bettembourg and Pétange, it was reported from studies, was too close to the surface and in a too densely populated area (Wort, 2012). It is thus technologically impossible to extract shale gas in Luxemburg. Different methods would have to be developed in order to make shale gas in Luxemburg extractable. Only then would the Luxembourg government reconsider (Wort, 2012).

According to a study dating back to 1993, Luxembourgian soil contains approximately 100 billion cubic metres of shale gas. "That is enough to quench the national energy needs for 20 to 30 years," said the social democratic member of the European Parliament, Robert Goebbels, an outspoken former economic affairs and energy minister who has criticized his country's "Denkverbot," or ban on thinking, about exploring for shale gas. (2012).

\section{Interregional}

\section{Benelux}

If we want to combine all of the above-mentioned regional political powers, we end up speaking about the Interparliamentary Benelux Consultative Council, better known as the Benelux Parliament, which was set up in 1955. Nicknamed "the testing ground for the European Union", it "provides the governments with advice on economic and cross-frontier cooperation. Its recommendations may also concern other matters if common interests or current events so dictate (Benelux Parliament, 2013)". However, it is doubtful that this parliamentary institution is going to play any significant role in energy policy in the future, as it is generally not viewed as a key player. A major issue within the Benelux Parliament is that it only meets three times per year. Introducing new policies here, certainly those where a lot of conflicting opinions and interests have to be managed, would take a lot of time. So far, its proceedings record basically no mention of unconventional gas.

\section{Dutch-Flemish cooperation}

A different picture emerges from more informal cross-border cooperation. In summer 2013, the Flemish and Dutch govern- ment teamed up for a trade mission to Texas. Usually, the federal government of Belgium organizes trade missions, but Flanders also has the authority to organize trade missions. During this high-profile journey, a delegation of some 90 business executives from both countries, led by Prime Ministers Mark Rutte and Kris Peeters, mostly visited the chemical industry in Texas. The Texas chemical firms and Texan ports, such as Houston, are important trade partners for the ports of Antwerp and Rotterdam, which both are major players in the European chemical sector.

In Texas, the Flemish and Dutch delegation visited the research facilities of ExxonMobil. The topic of discussion was shale gas. The message of ExxonMobil was clear: "Because shale gas is allowed in the U.S., the chemical industry currently has a big lead on the European. If Flanders and the Netherlands continue to lure investors, steps must be put to improve competitiveness" (VMMa, 2013).

It seems that both Rutte and Peeters have understood this message, as they afterwards said to plan a joint consultation on unconventional gas in the fall of 2013. The Flanders premier even indicated that the EU should change its view on shale gas. He said that "the message from ExxonMobil was not a threat but a warning" about competitiveness (VMMa, 2013). His Dutch colleague, Prime Minister Rutte, responded: "We should make sure that the amount of regulation on the European level decreases. Together [with Flanders], we will do everything possible to make this happen" (VTM Nieuws, 2013).

\section{Conclusion}

The different countries inside the Benelux area have a rather cautious attitude towards unconventional gas. They and their regions are in different stages of advancement in the policy domain, but at present no real drilling for unconventional gas has taken place.

Where we see a federal Belgium that is not really interested in the unconventional gas debate, the Netherlands, driven by domestic and foreign interests and at least half the government, are taking a leadership role within the Benelux. The Netherlands have also seen the broadest and most intense debate of the three countries.

Flanders has been rather skeptical about the extraction of shale gas, but at minimum has economic interests to protect connected to the port of Antwerp. Where we see Flanders skeptical about shale gas, the region takes a more positive position towards coalbed methane, because questionable and badly perceived fracking methods are not needed to extract the gas. But again, no permits or drilling has so far taken place.

Despite the Luxembourgian moratorium on "fracking," the government keeps the door open for alternative extraction methods, which at the moment are not available. In Wallonia, neither much debate nor policymaking can be tracked, but there is the intriguing activity of investor Albert Frère, which could put Wallonia on the map.

Many questions remain unanswered at present, and the Benelux seems to be in slow motion on unconventional gas. However, with the Dutch struggling forward and more likely progress in coalbed methane, the upcoming two years may see a lot more crucial discussion on shale- and perhaps a real push for action by investors. 


\section{References}

Belgian Commission for the Regulation of Electricity and Gas. (2012, January 31). De hoogte en de evolutie van de energieprijzen. Retrieved July 13, 2013, from CREG: http://www.creg.info/pdf/Studies/F1134NL.pdf

Benelux Parliament. (2013). Powers and composition. Retrieved July 15, 2013, from Benelux Parliament: http://www.beneluxparlement.eu/en/parlement/parlement_intro.asp

Collard. (2012, December 14). Integraal verslag van de vergaderingen. Retrieved July 16, 2013, from Raadgevende Interparlementaire Beneluxraad: http://www.beneluxparlement.eu/docs/02_PlenaireZitting/20121215-14_an_311-312.pdf

Cornet, P. (2013, February 12). The shale gas debate continues in Belgium. Retrieved July 18, 2013, from Shale gas Europe: http://www.shalegas-europe.eu/en/index.php/newsroom/blog/entry/update-the-shale-gas-debate-continues-in-belgium

Dart Energy Limited. (2011, May 02). Dart to Pursue CBM In Belgium Retrieved July 14, 2013, from Natural gas Europe: http://www.naturalgaseurope.com/dart-pursue-cbm-belgium

De Becker, A. (2013, February 02). Wathelet neemt "pragmatisch standpunt" in over schaliegas . Retrieved July 13, 2013, from Het Laatste Nieuws:

http://www.hln.be/hln/nl/2764/milieu/article/detail/1575886/2013/02/0 7/Wathelet-neemt-pragmatisch-standpunt-in-over-schaliegas.dhtml

De Klerk, S. (2012, March 05). Raad maakt Boxtel schaliegasvrij. Retrieved July 09, 2013, from De Telegraaf:

http://www.telegraaf.nl/binnenland/article20123109.ece

De Roo, M. (2013, July 08). Vlaanderen wil impact schaliegas onderzoeken. Retrieved July 09, 2013, from De Tijd: http://www.tijd.be/nieuws/politiek_economie_belgie/Vlaanderen_wil_ impact schaliegas onderzoeken.9372586-3137.art

DutchNews.nl. (2013, April 02). Opponents are winning the Dutch shale gas war. Retrieved June 09, 2013, from DutchNews.nl: http://www.dutchnews.nl/news/archives/2013/04/opponents_are_winni ng_the_dutc.php

Goebbels, R. (2012, July 27). Schiefergas in Luxemburg. Retrieved July 18, 2013, from Robbert Goebbels, MEP http://www.robertgoebbels.lu/schiefergas-in-luxemburg/

Government of the Netherlands. (2013). Gas. Retrieved July 16, 2013, from Energy: http://www.government.nl/issues/energy/gas

Grietens, E. (2013, January 25). Limburg Gas wil mijngas opsporen . Retrieved July 15, 2013, from Bond beter leefmilieu: http://www.bondbeterleefmilieu.be/page.php/30/693/14311

Heylen, K. (2013, July 03). Aardbeving gevoeld in Noord-Groningen. Retrieved July 05, 2013, from De redactie: http://www.deredactie.be/cm/vrtnieuws/buitenland/1.1668073

Le Soir. (2013, March 13). Albert Frère envisage d'exploiter le gaz dans les mines wallonnes. Retrieved July 18, 2013, from Le Soir: http://www.lesoir.be/206946/article/actualite/fil-info/fil-infoeconomie/2013-03-13/albert-frère-envisage-d'exploiter-gaz-présentdans-mines-wallonne

Marijnissen, H. (2013, April 17). Brouwers en bottelaars sluiten zich aan bij schaliegas-verzet . Retrieved July 18, 2013, from Trouw: http://www.trouw.nl/tr/nl/4332/Groen/article/detail/3427185/2013/04/ 17/Brouwers-en-bottelaars-sluiten-zich-aan-bij-schaliegasverzet.dhtml

Medvedev, A. (2013, March 28). Gazprom. Retrieved July 16, 2013, from Brandpunt reporter: http://www.uitzendinggemist.nl/afleveringen/1334204

Netherlands Organisation for Applied Scientific Research TNO. (2012, April). Licenses in the Netherlands. Retrieved July 12, 2013, from Shale gas information platform: http://www.shale-gas-informationplatform.org/typo3temp/pics/99d868d9f4.jpg

NOS. (2013, July 01). Rabobank tegen schaliegas. Retrieved July 03 , 2013, from Nieuws: http://nos.nl/artikel/524438-rabobank-tegenschaliegas.html

Postma, R. (2013, July 01). Studie naar effecten winning van schaliegas 'onvolledig'. Retrieved July 03, 2013, from NRC Handelsblad: http://www.nrc.nl/nieuws/2013/07/01/studie-naar-effecten-winningvan-schaliegas-onvolledig/

Queen Wilhelmina State Park. (2012). Queen Wilhelmina Lodge History. Retrieved July 17, 2013, from Her Majesty the Queen Wilhelmina of the Netherlands: http://www.visionmena.com/arkansas state \%20parks/queen_wilhelm ina.htm

Radio et Television de la Belgique francophone. (2013, April 13). Gaz de charbon, le nouvel or noir wallon? . Retrieved July 18, 2013, from RTBF: http://www.rtbf.be/info/economie/detail_gaz-de-charbon-lenouvel-or-noir-wallon?id $=7968315$

Simons, W. (2013, May 03). ECN: "Schaliegas niet noodzakelijk voor economie”. Retrieved July 17, 2013, from Energieoverheid: http://www.energieoverheid.nl/2013/05/03/ecn-schaliegas-nietnoodzakelijk-voor-economie/

Steinglass, M. (2013, August 26). Financial Times. Retrieved November 26, 2013, from Fracking: Netherlands moves closer to shale gas exploitation: http:/www.ft.com/cms/s/0/c20b1 e24-0e66-11e3-bfc800144 feabdc0.html

Te Velde, H. (2013, April 29). Willem-Alexander to refresh Netherlands monarchy . Retrieved July 17, 2013, from Euronews: http://www.euronews.com/2013/04/29/willem-alexander-to-refreshnetherlands-monarchy/

Thuwis, G. (2013, February 07). Shell wijst voorstel af wegens te duur. Retrieved July 12, 2013, from Het Belang van Limburg: https://aow.kuleuven.be/geologie/popularisering/pers/GazetvanAntwer pen20130207-Swennen.pdf

U.S. Energy Information Administration. (2011, April). World Shale Gas Resources: An Initial Assessment of 14 Regions Outside the United States. Retrieved June 02, 2013, from http://www.eia.gov/analysis/studies/worldshalegas/pdf/fullreport.pdf

UPI. (2013, September 23). UPI.com. Retrieved November 26, 2013, from Dutch decision to delay shale gas drilling brings mixed reactions: http://www.upi.com/Business_News/Energy-

Resources/2013/09/23/Dutch-decision-to-delay-shale-gas-drillingbrings-mixed-reactions/UPI-95861379909040/

Van Horenbeek, J. (2013, February 06). Shell opent jacht op Belgisch schaliegas . Retrieved July 17, 2013, from De Morgen: http://www.demorgen.be/dm/nl/996/Economie/article/detail/1574684/ 2013/02/06/Shell-opent-jacht-op-Belgisch-schaliegas.dhtml

Vanaudenhove, L. (2013, April 04). "Vijf bedrijven vroegen Vlaamse overheid info over regelgeving schaliegas". Retrieved July 09, 2013, from Het Laatste Nieuws:

http://www.hln.be/hln/nl/2764/milieu/article/detail/1608937/2013/04/0 4/Vijf-bedrijven-vroegen-Vlaamse-overheid-info-over-regelgevingschaliegas.dhtml

Vandenhove, L. (2013, April 22). Mijngas in Limburg: het is bijlange zover nog niet. Retrieved July 17, 2013, from Ludwig Vandenhove.be: http://www.ludwigvandenhove.be/nieuws/mijngas-limburg-hetbijlange-zover-nog-niet

Verberg, G. (2013, March 28). Gazprom. Retrieved July 13, 2013, from Brandpunt Reporter:

http://www.uitzendinggemist.nl/afleveringen/1334204

VMMa. (2013, July 09). 'Europa moet beleid schaliegas herzien' Retrieved July 18, 2013, from De Standaard: http://www.foodlog.nl/short-news/detail/exxonmobil-leert-rutte-de-lesover-schaliegas/

VTM Nieuws. (2013, July 09). Europa moet beleid schaliegas herzien. Retrieved July 19, 2013, from VTM Nieuws: http://nieuws.vtm.be/buitenland/52833-europa-moet-beleid-schaliegasherzien

Windhorst, G. (2012, February 14). Shale gas in the Netherlands. Retrieved July 15, 2013, from Aardgasupdate: http://www.youtube.com/watch? $\mathrm{v}=\mathrm{sZzPWvfLBdw}$

Wort. (2012, November 14). No fracking of shale gas in Luxembourg . Retrieved July 18, 2013, from Wort.lu: http://www.wort.lu/en/view/no-fracking-of-shale-gas-in-luxembourg50a37ff8e4b0e83edf95f923

Zijp, M. (2012, June). Schaliegas in Nederland. Retrieved July 17, 2013, from Geologische Dienst Nederland: http://www.geageologie.nl/informatie/tijdschrift/Gea/pdf/2012_02_Mart_Zijp_Schalie gas.pdf 